\title{
The Analysis of Teaching and Learning Reading Through Think-Aloud Method
}

\author{
Satria Adi Pradana \\ spsatriapradana@gmail.com \\ State Islamic University of Raden Intan Lampung
}

\begin{abstract}
Reading is needed by people around the world. The objectives of this research were to know process teaching and learning reading of using think-aloud method, to know teacher's problem in teaching reading of using think-aloud method and to know students' problem in learning reading of using think-aloud method. Qualitative was used in this research as a research design. Purposive sampling technique was used to determine the sample. The class of VIII $K$ was chosen as a sample which consisted of 37 students. In collecting the data, observation, interview and documentation were used. Three major phases of data analysis were used in this research, they were: data reduction, data display and data conclusion. This research was conducted in two meeting. After analyzing the data, there were three points of the result. First, the teacher did not apply some of steps in observation checklist, but it did not give the big influence in teaching and learning process. Second, the teacher's problem in teaching reading through think-aloud method were that the teacher had difficulty to handle the students in giving instruction to ask and also the teacher felt difficulty to manage the time in implementing think-aloud method in teaching reading. Third, the problem faced by the students in learning reading through think-aloud method was that the students could not remember information from the text although they were using think-aloud method.
\end{abstract}

Keywords: Think-aloud method, teaching reading, qualitative research.

\section{BACKGROUND}

In teaching English, the teacher has to teach English in proper way. In teaching English, teacher emerges some ideas to show the words in context. The teacher should have an interactive or interesting method or technique to teach English. Teacher should prepare the material and method well. By using target language, the students are able to be familiar to the language. Besides, there are four skills that should be mastered by students in learning English, they are Listening, Speaking, Reading and Writing. Reading is one of the skills elaborated before. One of the purposes of reading is to understand and get the meaning behind a text. Everyone has to pass the process of reading to explain and understand what they read by identifying the meaning of words.

In reading, people need to be able to identify the words used to convey meaning, and they must be able to construct meaning once they have identified the individual words in print (Center, 2005: 7). It implies that everyone has to pass the process of reading to explain and understand what they read by identifying the meaning of words. Hence, we as a reader can comprehend what the writer means. Moreover, we carry out these processes to get meaning in learning reading skill. The students must be able to apply these processes to comprehend the meaning. Besides, most of students still have low ability in understanding 
the text. They are not able to understand what the writer means because they do not get the point of reading.

In teaching English, sometime the teacher only invites one of the students to come forward and read the text which certainly they do not know the meaning of the text. Then the teacher invites some of the students to help him/her to open their dictionaries in knowing the meaning of some difficult words. Then, the teacher together with students, translate the text to comprehend the meaning. In this case, English teacher needs to teach students effectively, especially the students' reading skill, in order that the students have great motivation to read. The teacher can do the one of some ways in improving students' reading ability. It is through think-aloud method.

One of methods which suitable for students in teaching reading is think-aloud method. Think-aloud is a method in which readers report their thoughts while reading (Jahandar, et.al, 2012: 1). Thereby when a teacher teaches the students in the class using think-aloud method he/she will be able to achieve a better view of the mental processes in which students are engaged. Think-aloud helps to enhance students' ability of the thinking process and understand what they comprehend (Khatami, et.al, 2014: 381). Through thinking-aloud, teachers are able to vocalize how they think as they read.

\section{METHOD}

\section{Data Reduction}

Data reduction is the first component or level in model of qualitative data analysis of Miles and Huberman theory. It refers to the process of selecting, focusing, simplifying, abstracting and transforming the data that appear in written up field notes or transcription. In data reduction, the mass of data has to be organized and meaningfully reduced or reconfigured (Miles and Huberman, 1994: 12). In this case, there were three data collecting technique used to collect the data: observation, interview and questionnaire.

In the observation process, the blank note, observation checklist and camera were prepared to take some pictures in teaching and learning process. The data of observation has been identified as described in the following discussion:

\section{a. The First Observation}

In the first observation, it was conducted on Thursday, November $10^{\text {th }}, 2016$, at the 08:00 a.m.

\section{Pre-activity}

The teacher opened the class by greeting to the students and together read the Holy Qur'an with them. Then, the teacher checked the students' attendance. After that, the teacher asked previous lesson and explained the material that would be taught to the students.

2. While-activity

In the while-activity, the first the teacher has the students to be some groups. Then, the teacher gave the recount text and explained the purpose of the text that has been given to the students.

After all of the students held the text, the teacher gave the instruction to the students in using think-aloud method. Afterward, the teacher did think-aloud in front of the class to give an example to the students. After that, the teacher developed the set of questions:

- I predict that...

- I can picture... 
- I'm confused about...

- A question I have is...

- This reminds me of...

- This is like...

- The big idea here is...

After the students understood about how to do the think-aloud, the teacher gave the instruction to the students in discussion how to share the minds to each other. After that, the teacher gave opportunity to the students to model the method. Then, the teacher gave opportunity to the students to ask the questions.

After the students asked the questions, the teacher made the time to ask some questions to the students. After that, the teacher gave some exercises and helped the students performed the exercises. And then, when the students finished their exercises, the teacher has the students to come front of the class one by one to show their answers. After that, the teacher and students together checked the answer of the exercises.

3. Post-activity

In the post-activity, the teacher asked to the students about what have they learned and reviewed the material at home. Then, the teacher explained the material that would be taught to the next meeting. After that, the teacher closed the lesson.

\section{The Second Observation}

In the second observation, it was conducted on Thursday, November $17^{\text {th }}, 2016$, at the 09:00 a.m.

a. Pre-activity

The teacher opened the class by greeting to the students and together read the Holy Qur'an with them. Then, the teacher checked the students' attendance and asked previous lesson to the students.

b. While-activity

In the while-activity, the teacher has the students to be some groups. Then, the teacher gave the recount text to the students. After that, the teacher remind to the students about how to use the think-aloud and the set of questions.

After the teacher remind to the students, the teacher gave the opportunity to the students to model the method and to ask the questions. After the students asked the questions, the teacher asked to the students about the text as a feedback. After that, the teacher gave some exercises to the students and helped them performed the exercises.

After the students finished their exercise, the teacher and students together checked the answer of exercises.

c. Post-activity

In the post-activity, the teacher asked about what have learned and explained that would be taught to the next meeting. After that, the teacher closed the lesson.

\section{a. Interview}

To support the data of the observation, the interview was employed to the teacher to investigate the problem faced by her and her students during teaching and learning reading through think-aloud method. There were ten questions that the 
researcher asked to the teacher. The question number first to sixth was consisted of the teacher's problem and the rest were the students' problem.

\section{b. Questionnaire}

The questionnaire was employed to support the observation and interview data. The questionnaire consisted of seven questions. The first was to know think-aloud can help students in adding vocabulary in learning reading, the second to fourth were to know think-aloud can help the students in comprehending the text in learning reading, the fifth was to know think-aloud can help the students in reading retention, the sixth was to know think-aloud can help the students in answering questions in learning reading and the seventh was to know think-aloud can help the students in finding main idea in learning reading. Questionnaire was given to the whole of students in class VIII $\mathrm{K}$ which was consisted of 37 students.

\section{FINDINGS}

\section{a. Observation Report}

Based on the data showing in the data reduction, in this part the data were going to be identified and displayed for the two meetings.

\section{The First Observation}

a) Observation Sheet in the First Meeting

Here it is displayed the result of observation sheet from reduction data in teaching and learning process in the first observation that can be seen as follows:

Table 5

Observation Sheet in the First Meeting

\section{Components of Observation}

\section{A. Pre activity}

1. The teacher starts the class

2. The teacher checks the students' attendence list

3. The teacher explains the method and the material that will be taught

\section{B. While activity}

1. The teacher has the students to be some groups

2. The teacher begins by modeling the method

3. The teacher explains the purpose about chosen topic (text)

4. The teacher models his/her think as his/her read

Checklist Explanation
Yes No

The teacher started the class by greeting and read Holy Qur'an together with the students.

The teacher asked to the students who did not come today.

The teacher asked to the students about previous lesson. After it the teacher explained the material that would be taught.

The teacher had the students to be some groups.

The teacher gave and explained the purpose of the text to the students. 
5. The teacher does the thinkaloud at points in the text that may be confusing for the students

6. The teacher develops the set of the questions for the students :
a. What do I know about this topic?
b. What do I think I learn about this topic?
c. Do I understand what just I read?
d. Do I have a clear picture in my head about this information?
e. What more can I do to understand this?
f. What were the most important points in this reading?
g. What new information did I learn?

7. The teacher gives the students an instruction in discussion

8. The teacher gives opportunities to practice the method and offer feedback to students

9. The teacher reads the selected passage aloud as the students read the same text silently

10. The teacher asks questions to the students about text

11. The teacher demonstrates how good readers monitor their understanding by rereading a sentence, reading ahead to clarify, and looking for context clues

12. The teacher summaries the text and gives exercise to the students

13. The teacher and the students together check the exercise
The teacher did The think-aloud in front of the students (gave the example) after she gave the instruction in using think-aloud to them.

The teacher developed the set of questions:
a. I predict that...
b. I can picture...
c. I confused about...
d. A question I have is...
e. This remind me of...
f. This is like...
g. The big idea here is...

The teacher gave the instruction to the students in their discussion.

The teacher gave the opportunity to the students in modeling the method and asking the questions to the teacher.

The teacher asked the questions to the students about the text.

The teacher guided and gave some exercises to the students.

The teacher had the students came front of the class one by one. After 


\section{Post activity}

1. The teacher gives the feedback

2. The teacher closes the lesson it the teacher and students together

checked the exercises.

The teacher asked to the students to reviewe the material that has been learned.

The teacher explained the material that would be taught for the next meeting. After it the teacher closed the meeting.

Based on display of the observation sheet above, it found that the teacher did not apply all of the treatment. For example, The teacher did not demonstrates how good readers monitor their understanding by re-reading a sentence, reading ahead to clarify, and looking for context clues. So, the students did not apply and demonstrate the treatment in detail

\section{The Second Observation}

\section{a) Observation Sheet in the Second Meeting}

Like in the first meeting, the observation sheet also made based on observation guideline. It can be as follows:

Table 7

Observation Sheet in the Second Meeting

\begin{tabular}{|c|c|}
\hline Components of Observation & Checklist \\
\hline
\end{tabular}

\section{A. Pre activity}

1. The teacher starts the class

2. The teacher checks the students' attendence list

3. The teacher explains the method and the material that will be taught

\section{B. While activity}

1. The teacher has the students to be some groups

2. The teacher begins by modeling the method

3. The teacher explains the purpose about chosen topic (text)

4. The teacher models his/her think as his/her read

5. The teacher does the thinkaloud at points in the text that may be confusing for
The teacher started the class by greeting and read Holy Qur'an together with the students. The teacher asked to the students who did not come today. The teacher discussed the previous lesson to the students but did not explain the material that would be taught.

The teacher had the students to be some groups.

The teacher gave the text to the students. 
the students

6. The teacher develops the set of the questions for the students :

h. What do I know about this topic?

i. What do I think I learn about this topic?

j. Do I understand what just I read?

k. Do I have a clear picture in my head about this information?

1. What more can I do to understand this?

m. What were the most important points in this reading?

$\mathrm{n}$. What new information did I learn?

7. The teacher gives the students an instruction in discussion

8. The teacher gives opportunities to practice the method and offer feedback to students

9. The teacher reads the selected passage aloud as the students read the same text silently

10. The teacher asks questions to the students about text

11. The teacher demonstrates how good readers monitor their understanding by rereading a sentence, reading ahead to clarify, and looking for context clues

12. The teacher summaries the text and gives exercise to the students

13. The teacher and the students together check the exercise

\section{Post activity}

1. The teacher gives the feedback
The teacher reminds to the students about the set of questions and how to use think-aloud.

The teacher gave opportunity in modeling the method and asking the questions to the teacher.

The teacher asked the questions about the text to the students.

The teacher guided and gave some exercises to the students.

The teacher and students together checked the exercises.

The teacher asked to the students about what they have learned. 
2. The teacher closes the lesson
The teacher explained the material that would be learned for the next meeting. After it the teacher closed the meeting.

Based on the table of the second observation above, it found that the process teaching and learning reading through think-aloud method were not completed, many of components of the table above were empty, because the teacher did not apply all of the treatments in the table. It might be the studentshave already understood about the treatments that the teacher taught in previous meeting.

\section{a) Interview Report}

It can be seen in the dialogue below:

1. Interviewer: What are the basics should be mastered in teaching reading through think-aloud method?

Interviewee: Vocabulary exactly. And also a teacher must be able understand the text that will be given to students.

From the answer above, it can be concluded that the teacher has problem that be faced like text comprehension and vocabulary mastery.

2. Interviewer: What are the difficulties you find to handle the students when they have the habit of slow reading? So, what makes the students have the habit of slow reading?

Interviewee: I feel difficult to manage the time. The students who have the habit of slow reading certainly must be given much time to be used.

- Poor of vocabulary

- The students are seldom to read English text in their daily

- Poor of pronounce yield the students have the habit of slow reading

From the answer above, it can be concluded that the teacher feels difficult to manage the time, because the students has the criteria like poor of pronounce and vocabulary.

3. Interviewer: What are the difficulties you find to handle the students when they have difficulty to find out main idea in the text?

Interviewee: In class VIII K, I did not find difficulties in handling the students to determine main idea in the text.

From the answer above, it can be concluded that the teacher did not face difficulties in handling the students to determine main idea in the text.

4. Interviewer: What are the difficulties you find in choose a text that will be taught?

Interviewee: I did not find difficulty in choose any text.

From the answer above, the teacher makes simple respond and has no longwide. It means that the teacher did not wholeheartedly find difficulty in choose a text that will be taught.

5. Interviewer: What are the difficulties you find when give the instruction to the students in teaching reading through think-aloud method?

Interviewee: So far... praise to Allah, I never found difficulty in giving instructions to the students in think-aloud method.

From the answer above, it can be concluded that the teacher never find difficulty in giving instructions to the students in think-aloud method.

6. Interviewer: What are the difficulties you find when give feedback to the students in teaching reading through think-aloud method? 
Interviewee: The difficulty that I found when I have the students to ask, they only assumed to silent. I do not know it means understand or not. But, they have courage to ask when they have a group.

From the answer above, it can be concluded that the teacher has the difficulty when give feedback, because the students only silent. It is different when the teacher has the students to be some groups. They were brave to throw questions.

7. Interviewer: According to you, why the students have difficulty in decoding words?

Interviewee: I have said just now, poor of vocabulary.

From the answer above, it can be concluded that the reason why the students have difficulty in decoding the words, because they were poor of vocabulary.

8. Interviewer: According to you, why the students have difficulty in decoding sentences?

Interviewee: Lack of schema in reading, potential in remembering and ability in thinking.

From the answer above, it can be concluded that the reason why the students have difficulty in decoding sentences, because they had lack of schema in reading, potential in remembering and ability in thinking.

9. Interviewer: What are the factors make the students have difficulty to comprehend the text?

Interviewee: Poor of vocabulary. In the other hand, background knowledge and fluency are important in understanding a text.

From the answer above, it can be concluded that poor of background knowledge, fluency and vocabulary are able to make the students feel hard to comprehend the text.

10. Interviewer: What are the factors make the students have difficulty to remember information contained in the text?

Interviewee: I always asked to the students, "Review the lesson at home". In fact, they were ignored it. It may be make them feel difficult to remember information.

From the answer above, it can be concluded that the factor that make the students feel difficult to remember information, because they did not review the lesson at home.

Based on the result of the interview above, the teacher expressed some difficulties and problems in teaching reading through think-aloud method. The teacher felt difficulty to manage the time and the teacher felt difficulty to give instructions to the students to ask. In the other side, the students also have some difficulties in learning reading. The one of them, the students were poor of vocabulary.

\section{b) Questionnaire Report}

The questionnaire was distributed to the students by taking several minutes in the classroom. Here were the students' answers of questionnaire:

Table 9

Questionnaire Report

\begin{tabular}{llll}
\hline No. & Question & Answer & \\
\hline $\mathbf{1}$ & Apakah dengan metode think-aloud dapat membantu & Yes & No \\
& kalian menambah kosakata? & 31 & 0 \\
\hline
\end{tabular}


Based on the data of the first question above, all of the students agreed that the think-aloud method could help them in adding their vocabulary. It means the thinkaloud method could help the students in overcoming their vocabulary problem.

\begin{tabular}{llll}
\hline No. & Question & Answer & \\
\hline $\mathbf{2}$ & Apakah kalian sering mengalami kesulitan & Yes & No \\
& memahami kalimat dalam teks yang disajikan? & 21 & 10 \\
\hline
\end{tabular}

Based on the data of the second question above, there were twenty one students felt difficult in understanding sentences in the text and ten others felt easy in understanding sentences in the text. It could be concluded that the most of the students still faced difficulty in understanding the text that be given by the teacher.

\begin{tabular}{llll}
\hline No. & Question & Answer & \\
\hline 3 & Apakah dengan metode think-aloud dapat membantu & Yes & No \\
& kalian dalam memahami teks? & 28 & 3 \\
\hline
\end{tabular}

Based on the data of the third question above, it could be known that twenty eight students felt the think-aloud method could help them in understanding the text. There were three students still felt difficult in understanding the text. It means that the thinkaloud method could help the students in understanding the text.

\begin{tabular}{llll}
\hline No. & Question & Answer & \\
\hline 4 & Apakah dengan metode think-aloud dapat menambah & Yes & No \\
& pemahaman kalian dalam membaca? & 26 & 5 \\
\hline
\end{tabular}

Based on the data of the fourth question above, it could be known that there were twenty six students stated if the think-aloud method could increase their understanding in reading and five others stated if the think-aloud method could not help them in increasing their reading. It means that most of the students stated the think-aloud method could increase their understanding in reading.

\begin{tabular}{llll}
\hline No. & Question & Answer & \\
\hline $\mathbf{5}$ & Apakah dengan metode think-aloud dapat membantu & Yes & No \\
& $\begin{array}{l}\text { kalian mengingat informasi yang terdapat dalam } \\
\text { teks? }\end{array}$ & 14 & 17 \\
\hline
\end{tabular}

Based on the data of the fifth question above, there were fourteen students stated that the think-aloud method could help them in remembering information in the text. There were seventeen students stated that the think-aloud method could not help them in remembering information in the text. It could be concluded that the most of the students could not remember information in the text although they were used the thinkaloud method.

\begin{tabular}{llll}
\hline No. & Question & Answer & \\
\hline 6 & Apakah dengan metode think-aloud kalian masih & Yes & No \\
& $\begin{array}{l}\text { merasa kesulitan menjawab pertanyaan yang } \\
\text { diberikan oleh guru? }\end{array}$ & 8 & 23 \\
\hline
\end{tabular}

Based on the data of the sixth question above, there were twenty three students felt easy in answering the question. There were eight others felt hard in answering the 
question. It means that the think-aloud method could help the students in answering the question.

\begin{tabular}{llll}
\hline No. & Question & Answer & \\
\hline $\mathbf{7}$ & Apakah dengan metode think-aloud kalian masih & Yes & No \\
& kesulitan dalam menemukan main idea dalam teks? & 10 & 21 \\
\hline
\end{tabular}

Based on the data of the seventh question above, there were twenty-one students felt easy in finding main idea in the text and ten others felt difficult in finding main idea in the text. It means that the think-aloud method could help the students in finding main idea in the text.

From the result of the questionnaire, it showed that teaching and learning reading through think-aloud method was good and could increase the students' reading ability. It could be shown from the result of data questionnaire that the most of the students stated that learning reading through think-aloud method could improve their reading ability although there were also some of the students who were felt difficult in learning reading through think-aloud method.

\section{DISCUSSION}

\section{Process Teaching and Learning Reading Through Think-Aloud Method}

The observation was conducted in two meetings. After observing teaching and learning reading through think-aloud method twice were described as follow:

a. In the first meeting the teacher did not apply some of the steps in observation checklist.

b. In the second meeting the teacher also did not apply some of the steps in observation checklist.

It could be concluded that there were lost steps in the aspects that were observed in the observation. It indicated that teaching and learning reading through think-aloud method was being well applied by the teacher and students. Nevertheless, in teaching reading process the teacher was not maximal in implementing the treatment of thinkaloud method, because the teacher did not apply some of the steps in observation checklist.

\section{Teacher's problems During Teaching Reading through Think-Aloud Method}

Having conducted to research, some problems were found that faced by the teacher during the implementation of think-aloud method in teaching reading. They were as follow:

a. The teacher felt difficult to manage the time in implementing think-aloud method.

b. The teacher faced difficult when giving the instruction to the students to ask. But, the students only silent.

It could be concluded that the teacher could not handle the whole of the teaching and learning activities. The teacher still had difficulties in handling the time and students to ask.

\section{Students' Problems in Learning Reading through Think-Aloud Method}

The questionnaire was employed to know the students' problems in learning reading through think-aloud method. Based on result of the students' answer, the 
researcher concluded that the problem faced by the students was the most of the students could not remember information in the text although they were used the thinkaloud method.

The result of the questionnaire showed good result. The think-aloud method greatly helped the students in learning reading. Because by using think-aloud method, reading is easier to be learned.

\section{CONCLUSION}

Having discussed the result of the research, it can be concluded that: first, The process of teaching and learning reading through think-aloud method has been conducted. Teaching and learning process in the class was running well. Although, there were some steps in observation checklist was not applied by the teacher. The think-aloud method is not easy to be implemented by the teacher and students, because it needs much times to spend in learning reading. Second, the teacher's problems in teaching reading through think-aloud method were that the teacher had difficulty to manage the time and difficulty to handle the students to ask. Third, the students' problem in learning reading through think-aloud method was that the most of the students could not remember information in the text although they were used the think-aloud method.

\section{REFERENCES}

Arikunto, Suharsimi. 2006. Prosedure Penelitian. Yogyakarta: Rineka Cipta.

Budiharso, Teguh. 2004. Prinsip dan Strategi Pengajaran Bahasa. Surabaya: Lutfiansyah Mediatama.

Bowles, Melissa A. 2010. The Think-Aloud Controversy in Second Language Research. New York: Routledge.

Center, Yola. 2005. Beginning Reading. Auckland: ALLEN \& UNWIN.

Creswell, John W. 1994. Research Design Qualitative, Quantitative, and Mixed Methods Approaches. First Edition. Lincoln: Sage Publication.

Cline, Johnstone \& king. 2006. Focus Group Reactor To Three Definition of Reading : As Originally Develop and Support NARAP Goal 1. Minniepolis: National Accesible Reading Assessment Project.

Emilia, Emi. 2011. Peningkatan Genre-Based Dalam Pengajaran Bahasa Inggris: Petunjuk Untuk Guru. Bandung: Rizqi Press.

Jahandar, Shahrokh. Et.al. 2012. The Think-Aloud Method in EFL Reading Comprehension. International Journal Scientific \& Engineering Research. 3 (9). 19. Available on: http://www.ijser.org/researchpaper\%5CThe-Think-aloud-Methodin-EFL-ReadingComprehension. Accessed on: February, $23^{\text {rd, }} 2016$.

Khatami, Mohammad. Yaser Heydayrian and Vahid Bagheri. 2014. Investigating the Effect of Think-Aloud Strategy on Reading Comprehension Ability Among EFL Univesity Students. International Journal of language Learning and Applied Linguistic World. 5 (1). 381-392. Available on: http://www.ijllalw.org/finalversion5131.pdf. Accessed on: February, $23^{\text {rd, }} 2016$.

Lems, Kristin. Et.al. 2010. Teaching Reading to English Language Learner. New York: The Guildford Press. 
Lodico, Marguerita G. 2010. Methods in Educaional Research. New York: Wiley Imprint. Oster, L. 2001. Using the Think-Aloud for Reading Instruction. The Reading Teacher, 55(1). 64-69. Available on: http://indianacouncilforthesocialstudies.shuttlepod.org. Accessed on: February, $23^{\text {rd }}, 2016$.

Setiadi, Bambang. 2006. Metode Penelitian untuk Penelitian Bahasa Asing. Yogyakarta: Graha Ilmu.

Patel, M. F. and Praveen M. Jain. 2008. English Language Teaching. Vaishali Nagar: Sunrise.

S.Hedgchock. Et.al. 2009. Teaching Readers In English. New York: Routledge.

Sugiyono. 2011. Metode Penelitian Pendidikan Pendekatan Kuantitatif Kualitatif dan $R$ \& $D$. Bandung: ALFABETA. 